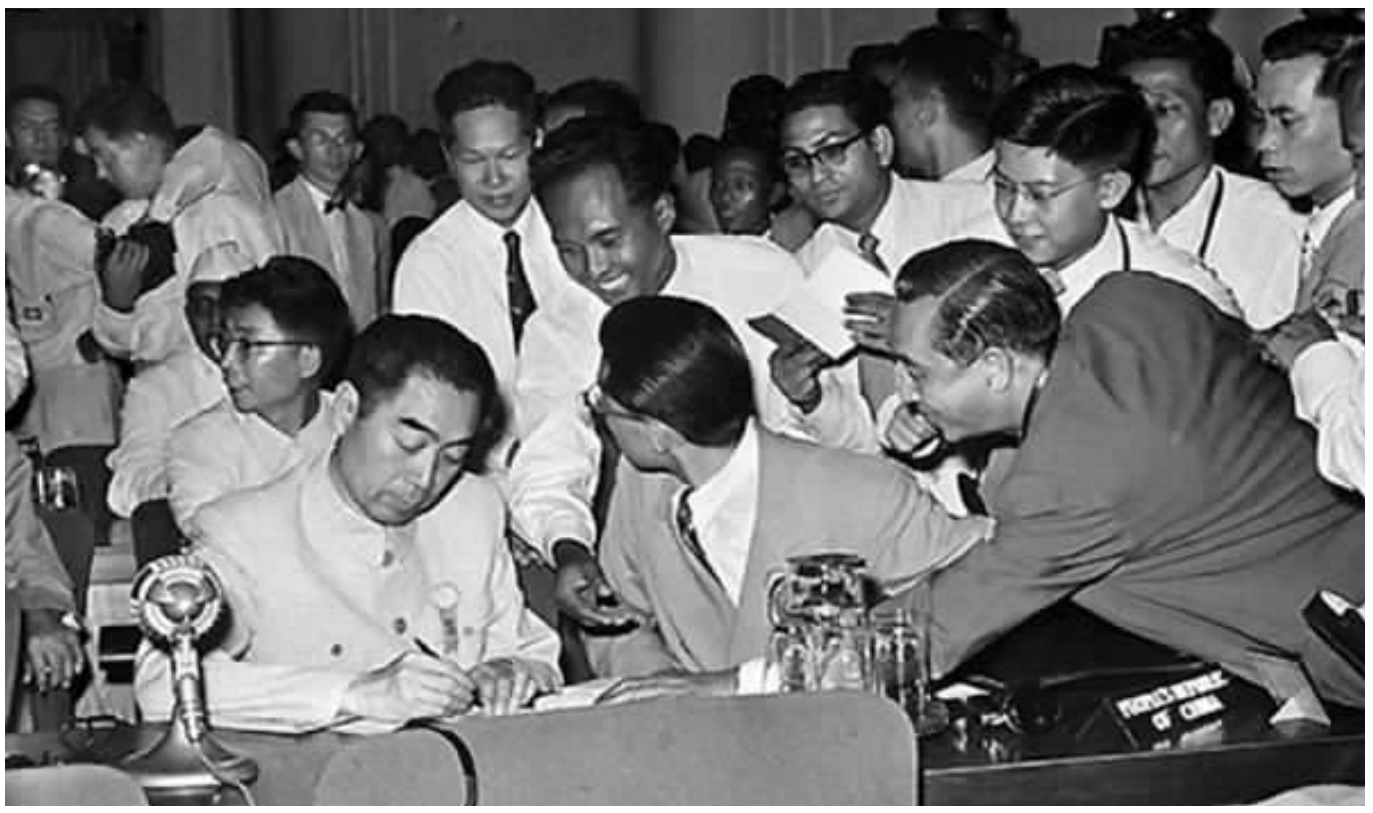

\section{The Past in the}

\section{Present of Chinese}

International

Development

Cooperation
Then-premier and foreign minister Zhou Enlai signs autographs for admirers on the sidelines of the AsianAfrican Conference, also known as the Bandung Conference, Bandung. Indonesia in April 1955. PC: Xinhua.

\section{Marina RUDYAK}

Tracing the origins of the core principles of China's foreign aid-political non-interference and aid for independent development-to the early days of the People's Republic of China, this essay shows how historical memory continues to play a significant role in China's interactions with developing countries today. It also argues that China's foreign aid from the past to the present has to be understood as an externalisation of China's quest for development, modernisation, and independence.

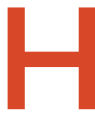
ow can China still claim to be a developing country when it is one of the biggest contributors to international development cooperation? I am asked this question a lot, most recently by a German parliamentarian. It appears that in the imaginative geographies of the West, a country is either a donor and thus developed or a recipient because it is developing (and poor). It is still generally overlooked that the origins of China's international development cooperation date back to the early days of the People's Republic of China (PRC). For most of its existence, the PRC-like India, for that matter-was simultaneously donor and recipient. Despite often being called a 'new' 
or 'emerging' donor, China has a longer history of aid giving than many of the so-called traditional donors-the common name for higher-income economies organised in the Development Assistance Committee (DAC) of the Organisation for Economic Co-operation and Development (OECD), which together provide the largest share of globally available aid.

The PRC started delivering aid in 1950, first providing military and economic assistance to the communist forces in North Korea and North Vietnam (Shi 1989: 23-30). Also, from 1950, communist China was a recipient of Soviet economic aid: concessional loans tied to the purchase of war materials, daily necessities, and equipment from the Soviet Union. After the Bandung Conference of 1955 , aid was extended to a steadily increasing number of countries in Southeast Asia and the newly decolonised sub-Saharan Africa. From the beginning, aid served as a tool for the PRC to break through its international isolation due to the US-led economic embargo and its exclusion from the United Nations, where the China seat was held by the Nationalist Party in Taiwan. Framed in terms of 'mutual benefit', while catering to the recipients' economic needs, foreign aid facilitated the PRC's diplomatic recognition and was instrumental in securing communist China the UN seat in 1971.

It may come as a surprise to many today that throughout the 1960s and 1970s, Chinese aid, particularly to Africa, received a fair amount of attention in the West. Wolfgang Bartke (1975) and John F. Copper (1976) provided detailed overviews of Chinese aid projects. Others wrote that China won praise from African nations for providing aid free of political strings, particularly through the construction of the Tanzania-Zambia Railway in the early 1970s (Hutchinson 1976; see also Monson's essay in the present issue), and that the United States, and even to some extent the Soviet Union, perceived China as an actor that could share the burden of providing aid to developing states (Weinstein 1975). In short, Chinese aid was an acknowledged part of China's global interactions. However, once China became a recipient of Western development aid after 1978, the West, to quote Deborah Bräutigam (2009: 54), 'stopped looking'. But China never stopped giving. Throughout the 1980s, it remained among the 10 largest donors to sub-Saharan Africa (OECD 1987: 8). It was only in 2005 that China came again under the spotlight when Angola chose a Chinese loan for which it could pay with oil exploration rights over an International Monetary Fund (IMF) aid package that was conditioned on governance reforms (Schmitz 2021). DAC countries began to worry that China's 'no-strings-attached' aid might undercut DAC's insistence on high requirements for good governance, environmental standards, or linking aid with poverty reduction indicators (Manning 2006). The issue of (non-)conditionality remains a key point of friction between China and the DAC.

\section{Historical Memory}

When the chair of the DAC, Richard Manning, visited Beijing in February 2007 as part of the DAC's effort to socialise China into the existing aid regime, he raised the issue of non-conditionality of Chinese aid. The Chinese side responded that China would not give up non-conditionality because of the principle of non-interference, which was linked to the memory in China of the Western embargo after 1949 (OECD 2007).

Historical memory is very much present in today's Chinese discourses on aid and development cooperation. Chinese leaders often invoke an image of a shared past of joint anti-imperial and anticolonial struggle with other developing countries, when China, despite its poverty, supported others to the best of its ability-and without any political conditions (except for the One-China Principle). Euro-American debates often dismiss such references to historical memory as 'propaganda'. Undoubtedly, the Chinese Government employs them strategically, but it would be wrong to infer that historical memory has no significance. In a language in which verbs do not have a past tense, the past is never gone. The constant quasi-ritual repetition and referencing of sites of historical memory-a concept French historian Pierre Nora (1989) popularised as 'lieux de mémoire'-imply that 
the realms of memory are ingrained into collective political consciousness as something that (still) 'is'.

The white paper on China's International Development Cooperation in the New Era (新时代的中 国国际发展合作) of January 2021 (SCIO 2021) may talk about the "new ideas and initiatives such as the global community of the Shared Future of Mankind and the Belt and Road Initiative' proposed by President Xi Jinping. However, the core of the development cooperation policy set out in the document essentially corresponds to what Zhou Enlai-whom I would call the father of Chinese aid-set out in 1964 in the Eight Principles of China's Economic and Technical Foreign Aid (中 国政府对外经济技术援助的八项原则), including equality and mutual benefit, political non-interference, improving people's livelihoods, supporting the recipient countries' capacity for independent development, and a technology-centred outlook on modernisation. The Eight Principles were spelled out by Zhou during his visit to 10 African countries (Egypt, Algeria, Morocco, Tunisia, Ghana, Mali, Guinea, Sudan, Ethiopia, and Somalia) between 24 December 1963 and 29 February 1964, which was described by contemporaries as 'Peking's greatest diplomatic effort to date outside the Communist world' (Adie 1964: 174) and laid the foundations for China's continuous engagement with Africa. The Eight Principles could be considered the offshoot of a long chain of ideas about international relations and development, some of which emerged during the Civil War and can even be traced back to Sun Yat-sen. All were rooted in China's own perspective and experiences as an aid supplicant and recipient. Therefore, by and large, foreign aid can be understood as an externalisation of China's quest for development, modernisation, and independence.

\section{Non-Interference}

Aid based on principles of non-interference and no political conditionality (except the One-China Principle) emerged as a countermodel to US President Harry S. Truman's Point Four Program-a technical assistance program for 'underdeveloped areas', which promised they could benefit from the United States' advanced industrial and scientific position to overcome their poverty (Truman 1949).

John F. Copper (1976), who wrote one of the earliest works about Chinese aid, has argued that the Chinese Communist Party (CCP) from the very beginning denounced aid provided by the United States and other Western countries for ideological reasons (Copper 2016: 88-89). However, lesser-known primary sources indicate that the CCP's leaders were less ideological than often assumed in the literature (Copper 2016; Brazinsky 2017). US diplomatic cables declassified in 1969 document implicit and explicit requests for US economic aid by the Chinese communists between 1945 and 1949. The first major foreign policy document of the CCP Central Committee (CCPCC), 'Instructions of the CCPCC on Diplomatic Work' (中共 中央关于外交工作的指示), published in August 1944 (a month after the Bretton Woods Conference that established the World Bank and the International Monetary Fund), stated that the CCP would 'welcome international investment and technical co-operation under the principle of mutual benefit' (NAAC 1992: 317). In January 1945, Mao Zedong and Zhou secretly tried approaching US President Franklin Delano Roosevelt to ask for US economic assistance. According to US Embassy cables, Mao explained his request by stating that 'China's greatest post-war need [was] economic development', but it lacked 'the capitalistic foundation necessary to carry this out alone'. He saw the United States as the only country with the economic capacity to meet China's needs (FRUS 1945). Such a statement appears to contradict Mao's known general scepticism of the United States, but this apparently did not extend to Roosevelt. Mao reportedly praised Roosevelt's policies towards China and viewed him as a representative of progressive forces in the US Government, even comparing him positively to Sun Yat-sen (Westad 1993: 61-69). Mao offered raw materials and agricultural products in exchange for capital to build up light industry, and promised in exchange that China, for the time being, would not pursue socialism or collectivisation: 
Neither the farmers nor the Chinese people as a whole are ready for socialism. They will not be ready for a long time to come. It will be necessary to go through a long period of private enterprise, democratically regulated. To talk of immediate socialism is 'counterrevolutionary' because it is impractical and attempts to carry it out would be self-defeating. (FRUS 1945)

Whether Mao meant what he said is open to debate, as his wish never materialised. Roosevelt died in March 1945 and his successor, Truman, declared unconditional support for the Nationalist Party. Mao declared in Yan'an on 13 August 1945 that the communists would pursue zili gengsheng (自力更生)一a term that is typically translated as 'self-reliance' but rather means regeneration through one's own effort. The idea of self-reliance was originally introduced by Mao during the second Sino-Japanese War (1937-45), when the communists had to cope with the economic isolation of their bases in various parts of rural China, and would become not only a principle of domestic development but also a goal of China's foreign aid from the 1950s-that is, to help other developing countries become 'self-reliant' (Yang 2019).

Before that, nonetheless, the US diplomatic cables document that after the launch of Truman's Point Four Program, there was another attempt to secure US aid. On 31 May 1949, one month before Mao announced that the new republic he envisioned would 'lean to one side' (一边倒) towards the Soviet Union in its foreign policy, the US Consulate in Beiping (now Beijing) received a secret oral message passed on from Zhou. The message said Zhou did not trust the Soviet Union and did not believe it could provide the help China needed; only the United States could. China, in his eyes, was on the brink of collapse, 'in such bad shape that [the] most pressing need [was] reconstruction without regard [to] political theories'. China would accept aid in the form of loans, technical assistance, or other help of Marshall Plan nature from the United States or Britain, 'if presented on the basis of equality with no strings detrimental to Chinese sovereignty attached' (FRUS 1949). The authenticity and sincerity of Zhou's message, which is known as the 'Zhou Démarche', have been widely debated in the literature and remain one of the great unresolved questions in China studies to this day (see, for example, Shaw 1982; Westad 1993; Zhang 2001; Heinzig 2015). However, given the similarities to Mao's request to Roosevelt in 1945, it appears plausible that there had been a general preference for US assistance, but Mao shifted his position during the Civil War.

Like the Truman Doctrine and the Marshall Plan, 'Point Four' was part of American Cold War policy, aimed at containing the expansion of Soviet influence. If Zhou had envisioned China as one of the 'undeveloped areas' to benefit from the program's resources, the final response was that China stood on the wrong side. Therefore, Zhou's subsequent sharp criticism of US aid as 'so-called aid' (所谓援助) - that is, aid that was conditional on political alignment and not primarily oriented towards the economic needs of the recipients-was arguably not just ideological but also rooted in US refusal to provide economic assistance for political reasons. Speaking to Party cadres in December 1949, on the eve of China's first aid program, Zhou painted a contradiction between the United States, which only granted aid to those who politically aligned with it by 'surrendering to US imperialism' (向美帝国主义屈服), and China's idea of 'equality and mutual assistance' (平等互助) for 'self-reliance' (Zhou 1949).

Its experience as a recipient of Soviet aid may also have played its part in the formation of China's non-interference policy, even though it rarely features in China's official historical memory today. Archival sources suggest that early Soviet aid to China was conditional on China's involvement in the Korean War. Chinese historian Shen Zhihua (2003: 398) maintains that about 48 per cent of all Soviet loans between 1950 and 1953 were rechannelled to North Korea, making the war highly expensive for China. According to Soviet sources, Zhou Enlai travelled to Moscow in 1952 to propose to Joseph Stalin a strategy to end the Korean War (Stanley 2009: 73). Stalin, however, made clear that the Soviet Union would only provide further economic assistance to China on the condition that China continued its involvement in the war (Stanley 2009: 73). Quite possibly to show its 
moral superiority over the Soviet Union, China announced in 1953 that it would forgive North Korea all the loans (People's Daily 1953: 1) -which was remarkable considering they were financed with Soviet concessional loans that China itself had to repay.

\section{Joint Self-Strengthening}

When giving his welcoming address at the SouthSouth Cooperation Roundtable hosted by China during the UN Sustainable Development Goals (SDGs) Summit in 2015, President Xi Jinping started by invoking historical memories:

\section{South-South Cooperation started in the days when we fought together against imperi- alism and colonialism and flourished in the era of economic globalisation. It is the great endeavour of developing countries of joint self-strengthening and opens a new path towards common development and pros- perity. (Xi 2015)}

The purpose of Chinese aid was to 'help developing countries to develop their economies and to improve the people's livelihood' (帮助发展中 国家发展经济, 改善民生) and to 'enhance their capacities for independent development' (提高自 身发展的能力). Here, Xi's linking of anti-imperial and anti-colonial struggle with joint self-strengthening (联合自强) and independent development echoes both Mao's ideology of 'self-reliance' and the anti-colonial Self-Strengthening Movement (自强运动) of 1861-95. His understanding of development primarily as a technocratic modernisation process, which is the basic prerequisite for improving people's livelihoods, on the other hand, can be traced back to Sun Yat-sen and his minsheng (民生) philosophy (sometimes translated as 'wellbeing').

Minsheng was part of Sun's Three Principles of the People (三民主义) (Linebarger 1937). The realisation of minsheng by means of economic and industrial development programs was seen by Sun as a necessary prerequisite for the other two principles: 'nationalism' (民族主义), which meant opposition to foreign imperialism, and the 'right to self-determination' (自决权) (Linebarger 1937: 243). Minsheng was also the centrepiece of Sun's 1918 book, The International Development of China (Sun 1920; originally published in English and later translated into Chinese with the title 实 业计划 [Industry Plan]), which the development economist William Easterly (2014: 53) termed 'the world's first development plan'. Sun, Easterly (2014: 53) argues, 'was one of the first to present the idea of technocratic development in its modern form'. Sun proposed the creation of a new form of international organisation (国际组织) that would facilitate China's development by introducing into the country foreign capital, technology, and expertise; the world would benefit from China's resources, while China would, in exchange, get the means for its economic and industrial revolution (Sun 1920:v). Although he held no official position at that time, Sun was hoping to mobilise international assistance for his development goals and sent his proposal to the 1919 Paris Peace Conference as well as to the US, British, and Italian governments (Helleiner 2014: 377). Even though he ultimately failed to get the support of the League of Nations, his ideas remained influential and were channelled by Chiang Kai-shek's government into the Bretton Woods agreement in 1944 (Helleiner 2014: 377). Much later, the model he proposed was reflected in the main pattern of China's engagement with other developing countries, including what became known as the 'Angola model' where China finances the infrastructure development of the country in exchange for access to its resources.

The Chinese official discourse today draws a link between Sun's ideas and China's relations with developing countries. Specifically, Chinese aid scholars frequently point to a quote from an essay written by Mao in 1956 to commemorate Sun-'China should make a greater contribution to mankind' (Mao 1977) - to explain the long-held sense of internationalist responsibility that guided China's aid giving (Zhou 2009; Liu 2015). Hereby, the domestic quest for modernisation and independence was extended to all 'underdeveloped' (不发达) countries. In an interview with American journalist Anna Louise Strong in Yan'an in 
1946, Liu Shaoqi, who was among the CCP's core leadership, linked China's transition to a more industrialised economy with national independence, arguing that the course chosen by China would influence Southeast Asian countries facing similar conditions (Strong 1947: 182). After the 1955 Bandung Conference, Zhou Enlai (1956) explained to the National People's Congress that the reason China wanted to support the economic development of other countries was its own recognition that political independence depended on economic independence:

\section{China is a country that just recently has been liberated. Our economy is still very backward; we still haven't achieved full economic inde- pendence ... But we have understood that economic independence is of major signif- icance for consolidating political indepen- dence. Therefore, while we advance the building up of our own economy, we wish, within the bounds of our possibilities, to contribute our meagre forces to help the economic development of other countries.}

Similarly, the Chinese official discourse today is extending the Chinese Dream (中国梦) to a 'World's Dream' (世界梦) and a 'Community of Common Destiny' (命运共同体) (SCIO 2014) in which China is depicted as ready to share its unique development lessons with other developing countries. However, joint self-strengthening is not only an objective but also a precondition for development: it is only through joint self-strengthening that China (or any country) can truly develop. For Zhou, aid was a tool for China to develop its foreign relations and to pursue an independent and peaceful foreign policy' (独立自主和平外交政 策) (Lin 1987). In 1979, Deng Xiaoping elaborated that China needed a peaceful international environment for development and therefore, no matter whether it was poor or rich, it had to give aid as aid was 'an indispensable strategic expenditure' (不可缺少的战略支出) (PLRC 1982). Similarly, Yang Jiechi, then State Councillor and China's top diplomat, stressed in 2013 that 'since the "Chinese dream" is closely linked with the dreams of other peoples around the world, China is committed to helping other countries' (Yang 2013). Therefore, from the Mao era until today, China's aid giving can be seen as shaped by the objective to gain relational security and increase relational power, and guided by an underlying assumption that aid, by and large, will ultimately be reciprocated with political allegiance (Qin 2018).

\section{The Centre is Still West}

The Chinese Government has long rejected the normative centrality of Western donors. Instead, it argues for a legitimately different mode of South-South cooperation-one, as President Xi noted in his 2015 UN SDG Summit speech, that is in line with China's Five Principles of Peaceful Coexistence (和平共处五项原则) and is based on 'non-interference in internal affairs' and 'respect for independent choice of development paths and social systems' (Xi 2015). Yet, only a few moments later in the same speech, Xi presented a clearcut vision of how the 'joint self-strengthening' is supposed to happen:

South-South Cooperation in the new era should aim at promoting the alignment of national development strategies ... We need to identify priority areas for cooperation, and promote cooperation in the areas of trade, finance, investment, infrastructure, and green environment protection, in order to improve the overall competitiveness of developing countries ... We need to make connectivity and production capacity cooperation a priority and focus on implementing landmark projects of strategic significance. We need to build our own financing platforms, and make full use of new mechanisms including the Asian Infrastructure Investment Bank and the New Development Bank of BRICS countries [Brazil, Russia, India, China, and South Africa] to provide stronger impetus for South-South Cooperation. (Xi 2015) 
The path outlined by Xi is both technology-centred and China-led. Xi's outlook may leave space for other countries to choose alternative social systems, but his imagining of how economic development should happen seems hardly different from what the West has championed. In the economic realm, the West continues to be the benchmark when it comes to the meaning of being 'developed' (admittedly, as the ongoing COVID-19 crisis reveals, this may be shifting, too).

Thus, China's development cooperation policyboth in foreign aid and in the Belt and Road Initiative-may rhetorically challenge the Western development paradigm, its benchmarks for defining development, and its prevalent exclusion of the possibility of learning from each other (Campbell 2008: 98-99). But China never contests the notions of 'developed' and 'underdeveloped', even though the implicit assumption in these concepts of the unity and superiority of Western-style modernity has been severely criticised by postcolonial theorists (see, for instance, Escobar 1995; Wainwright 2008). Nor is there critical discussion of the fact that building roads, developing raw materials, and modernising agriculture bring not only benefits but also costs-particularly to indigenous peoples, small farmers, forest-reliant people, and the poorest (Mawdsley 2012: 265). In that, China's international development cooperation policy appears to be an externalisation of its domestic development and modernisation ideology. In the Party-State's official discourse, China had to make development and economic modernisation a state ideology after suffering 'semi-colonialism' and a 'century of national humiliation' to ensure its political independence and ultimately realise the Chinese Dream of returning to the centre. This imagination leads to the assumption that other developing countries will want to follow the same development path as China. And thus, development becomes not merely a right but also a duty, while the benchmarks of the desirable state of being 'developed' are still modelled on the West. 
This text is taken from Made in China Journal: Volume 6, Issue 2, 2021, edited by Ivan Franceschini and Nicholas Loubere, published 2021 by ANU Press, The Australian National University, Canberra, Australia.

doi.org/10.22459/MIC.06.02.2021.10 